\title{
Eicosanoid turnover (version 2019.5) in the IUPHAR/BPS Guide to Pharmacology Database
}

\author{
Angelo A. Izzo $^{1}$ and Jane A. Mitchell ${ }^{2}$ \\ 1. University of Naples Federico II, Italy \\ 2. Imperial College London, UK
}

\begin{abstract}
Eicosanoids are 20-carbon fatty acids, where the usual focus is the polyunsaturated analoguearachidonic acid and its metabolites. Arachidonic acid is thought primarily to derive from phospholipase A2 action on membrane phosphatidylcholine, and may be re-cycled to form phospholipid through conjugation with coenzyme $A$ and subsequently glycerol derivatives. Oxidative metabolism of arachidonic acid is conducted through three major enzymatic routes: cyclooxygenases; lipoxygenases and cytochrome P450-like epoxygenases, particularly CYP2J2. Isoprostanes are structural analogues of the prostanoids (hence the nomenclature D-, E-, Fisoprostanes and isothromboxanes), which are produced in the presence of elevated free radicals in a nonenzymatic manner, leading to suggestions for their use as biomarkers of oxidative stress. Molecular targets for their action have yet to be defined.
\end{abstract}

\section{Contents}

This is a citation summary for Eicosanoid turnover in the Guide to Pharmacology database (GtoPdb). It exists purely as an adjunct to the database to facilitate the recognition of citations to and from the database by citation analyzers. Readers will almost certainly want to visit the relevant sections of the database which are given here under database links.

GtoPdb is an expert-driven guide to pharmacological targets and the substances that act on them. GtoPdb is a reference work which is most usefully represented as an on-line database. As in any publication this work should be appropriately cited, and the papers it cites should also be recognized. This document provides a citation for the relevant parts of the database, and also provides a reference list for the research cited by those parts.

Please note that the database version for the citations given in GtoPdb are to the most recent preceding version in which the family or its subfamilies and targets were substantially changed. The links below are to the current version. If you need to consult the cited version, rather than the most recent version, please contact the GtoPdb curators.

\section{Database links}

\section{Eicosanoid turnover}

http://www.guidetopharmacology.org/GRAC/FamilyDisplayForward?familyld=243

Cyclooxygenase

http://www.guidetopharmacology.org/GRAC/FamilyDisplayForward?familyld=269

Enzymes

COX-1

http://www.guidetopharmacology.org/GRAC/ObjectDisplayForward?objectld=1375

COX-2

http://www.guidetopharmacology.org/GRAC/ObjectDisplayForward?objectld=1376 
Prostaglandin synthases

http://www.guidetopharmacology.org/GRAC/FamilyDisplayForward?familyld=270

Enzymes

Thromboxane synthase(CYP5A1)

http://www.guidetopharmacology.org/GRAC/ObjectDisplayForward?objectld=1353

Prostacyclin synthase(CYP8A1)

http://www.guidetopharmacology.org/GRAC/ObjectDisplayForward?objectld=1356

mPGES1

http://www.guidetopharmacology.org/GRAC/ObjectDisplayForward?objectld=1377

mPGES2

http://www.guidetopharmacology.org/GRAC/ObjectDisplayForward?objectld=1378

cPGES

http://www.guidetopharmacology.org/GRAC/ObjectDisplayForward?objectld=1379

L-PGDS

http://www.guidetopharmacology.org/GRAC/ObjectDisplayForward?objectld=1380

H-PGDS

http://www.guidetopharmacology.org/GRAC/ObjectDisplayForward?objectld=1381

AKR1C3

http://www.guidetopharmacology.org/GRAC/ObjectDisplayForward?objectld=1382 CBR1

http://www.guidetopharmacology.org/GRAC/ObjectDisplayForward?objectld=1383

HPGD

http://www.guidetopharmacology.org/GRAC/ObjectDisplayForward?objectld=1384

Lipoxygenases

http://www.guidetopharmacology.org/GRAC/FamilyDisplayForward?familyld=271

Enzymes

5-LOX

http://www.guidetopharmacology.org/GRAC/ObjectDisplayForward?objectld=1385 12R-LOX

http://www.guidetopharmacology.org/GRAC/ObjectDisplayForward?objectld=1386

12S-LOX

http://www.guidetopharmacology.org/GRAC/ObjectDisplayForward?objectld=1387

15-LOX-1

http://www.guidetopharmacology.org/GRAC/ObjectDisplayForward?objectld=1388

15-LOX-2

http://www.guidetopharmacology.org/GRAC/ObjectDisplayForward?objectld=1389

E-LOX

http://www.guidetopharmacology.org/GRAC/ObjectDisplayForward?objectld=1390

Leukotriene and lipoxin metabolism

http://www.guidetopharmacology.org/GRAC/FamilyDisplayForward?familyld=272

Enzymes

Leukotriene C4 synthase

http://www.guidetopharmacology.org/GRAC/ObjectDisplayForward?objectld=1391

y-Glutamyltransferase

http://www.guidetopharmacology.org/GRAC/ObjectDisplayForward?objectld=1392

Dipeptidase 1

http://www.guidetopharmacology.org/GRAC/ObjectDisplayForward?objectld=1393

Dipeptidase 2

http://www.guidetopharmacology.org/GRAC/ObjectDisplayForward?objectld=1394

Leukotriene $\mathrm{A}_{4}$ hydrolase

http://www.guidetopharmacology.org/GRAC/ObjectDisplayForward?objectld=1395

\section{References}

1. Abdelgawad MA, Labib MB, Ali WAM, Kamel G, Azouz AA and El-Nahass ES. (2018) Design, synthesis, analgesic, anti-inflammatory activity of novel pyrazolones possessing aminosulfonyl pharmacophore as inhibitors of COX-2/5-LOX enzymes: Histopathological and docking studies. Bioorg. Chem. 78: 103-114 [PMID:29550530] 
2. Adams JL, Smothers J, Srinivasan R and Hoos A. (2015) Big opportunities for small molecules in immunooncology. Nat Rev Drug Discov14: 603-22 [PMID:26228631]

3. Aritake K, Kado Y, Inoue T, Miyano M and Urade Y. (2006) Structural and functional characterization of HQL-79, an orally selective inhibitor of human hematopoietic prostaglandin D synthase. J. Biol. Chem. 281: 15277-86 [PMID:16547010]

4. Auerbach SS and DrugMatrix $\AA$ and ToxFX $\AA$ Coordinator National Toxicology Program.. National Toxicology Program: Dept of Health and Human Services.

5. Bayly Cl, Black WC, Léger S, Ouimet N, Ouellet M and Percival MD. (1999) Structure-based design of COX-2 selectivity into flurbiprofen. Bioorg. Med. Chem. Lett. 9: 307-12 [PMID:10091674]

6. Beswick P, Bingham S, Bountra C, Brown T, Browning K, Campbell I, Chessell I, Clayton N, Collins S and Corfield J et al.. (2004) Identification of 2,3-diaryl-pyrazolo[1,5-b]pyridazines as potent and selective cyclooxygenase-2 inhibitors. Bioorg. Med. Chem. Lett. 14: 5445-8 [PMID:15454242]

7. Bhagwat SS, Gude C, Boswell C, Contardo N, Cohen DS, Dotson R, Mathis J, Lee W, Furness P and Zoganas H. (1992) Thromboxane receptor antagonism combined with thromboxane synthase inhibition. 4. 8-[[(4-Chlorophenyl)sulfonyl]amino]-4-(3-(3-pyridinyl) propyl)octanoic acid and analogs. J. Med. Chem. 35: 4373-83 [PMID:1447738]

8. Bigby TD. (2000) The leukotriene C(4) synthase gene and asthma. Am. J. Respir. Cell Mol. Biol.23: 273-6 [PMID:10970815]

9. Bigby TD, Hodulik CR, Arden KC and Fu L. (1996) Molecular cloning of the human leukotriene C4 synthase gene and assignment to chromosome 5q35. Mol. Med. 2: 637-46 [PMID:8898379]

10. Black WC, Brideau C, Chan CC, Charleson S, Cromlish W, Gordon R, Grimm EL, Hughes G, Leger S and Li CS et al.. (2003) 3,4-Diaryl-5-hydroxyfuranones: highly selective inhibitors of cyclooxygenase-2 with aqueous solubility. Bioorg. Med. Chem. Lett. 13: 1195-8 [PMID:12643942]

11. Blobaum AL and Marnett LJ. (2007) Structural and functional basis of cyclooxygenase inhibition.J. Med. Chem. 50: 1425-41 [PMID:17341061]

12. Blobaum AL and Marnett LJ. (2007) Molecular determinants for the selective inhibition of cyclooxygenase2 by lumiracoxib. J. Biol. Chem. 282: 16379-90 [PMID:17434872]

13. Bonnard E, Poras H, Nadal X, Maldonado R, Fournié-Zaluski MC and Roques BP. (2015) Long-lasting oral analgesic effects of $\mathrm{N}$-protected aminophosphinic dual ENKephalinase inhibitors (DENKIs) in peripherally controlled pain. Pharmacol Res Perspect3: e00116 [PMID:25692029]

14. Bézière N, Goossens L, Pommery J, Vezin H, Touati N, Hénichart JP and Pommery N. (2008) New NSAIDs-NO hybrid molecules with antiproliferative properties on human prostatic cancer cell lines. Bioorg. Med. Chem. Lett. 18: 4655-7 [PMID:18667313]

15. Carter GW, Young PR, Albert DH, Bouska J, Dyer R, Bell RL, Summers JB and Brooks DW. (1991) 5lipoxygenase inhibitory activity of zileuton. J. Pharmacol. Exp. Ther. 256: 929-37 [PMID:1848634]

16. Chaaban I, Rizk OH, Ibrahim TM, Henen SS, EI-Khawass EM, Bayad AE, EI-Ashmawy IM and Nematalla HA. (2018) Synthesis, anti-inflammatory screening, molecular docking, and COX-1,2/-5-LOX inhibition profile of some novel quinoline derivatives. Bioorg. Chem. 78: 220-235 [PMID:29602046]

17. Chadli A, Bouhouche I, Sullivan W, Stensgard B, McMahon N, Catelli MG and Toft DO. (2000) Dimerization and $\mathrm{N}$-terminal domain proximity underlie the function of the molecular chaperone heat shock protein 90. Proc. Natl. Acad. Sci. U.S.A. 97: 12524-9 [PMID:11050175]

18. Chen X, Wang S, Wu N and Yang CS. (2004) Leukotriene A4 hydrolase as a target for cancer prevention and therapy. Curr Cancer Drug Targets 4: 267-83 [PMID:15134534]

19. Chowdhury MA, Abdellatif KR, Dong Y, Das D, Yu G, Velázquez CA, Suresh MR and Knaus EE. (2009) Synthesis and biological evaluation of salicylic acid and $\mathrm{N}$-acetyl-2-carboxybenzenesulfonamide regioisomers possessing a N-difluoromethyl-1,2-dihydropyrid-2-one pharmacophore: dual inhibitors of cyclooxygenases and 5-lipoxygenase with anti-inflammatory activity. Bioorg. Med. Chem. Lett. 19: 6855-61 [PMID:19884005]

20. Dixon RA, Diehl RE, Opas E, Rands E, Vickers PJ, Evans JF, Gillard JW and Miller DK. (1990) Requirement of a 5-lipoxygenase-activating protein for leukotriene synthesis. Nature 343: 282-4 [PMID:2300173]

21. EI-Nagar MKS, Abdu-Allah HHM, Salem OIA, Kafafy AN and Farghaly HSM. (2018) Novel N-substituted 5aminosalicylamides as dual inhibitors of cyclooxygenase and 5-lipoxygenase enzymes: Synthesis, biological evaluation and docking study. Bioorg. Chem. 78: 80-93 [PMID:29550533]

22. Faull AW, Brewster AG, Brown GR, Smithers MJ and Jackson R. (1995) Dual-acting thromboxane receptor antagonist/synthase inhibitors: synthesis and biological properties of [2-substituted-4-(3-pyridyl)1,3-dioxan-5-yl] alkenoic acids. J. Med. Chem. 38: 686-94 [PMID:7861416]

23. Fischer L, Steinhilber D and Werz O. (2004) Molecular pharmacological profile of the nonredox-type 5- 
lipoxygenase inhibitor CJ-13,610. Br. J. Pharmacol. 142: 861-8 [PMID:15197110]

24. Fürstenberger G, Marks F and Krieg P. (2002) Arachidonate 8(S)-lipoxygenase.Prostaglandins Other Lipid Mediat. 68-69: 235-43 [PMID:12432921]

25. Garscha U, Romp E, Pace S, Rossi A, Temml V, Schuster D, König S, Gerstmeier J, Liening S and Werner M et al.. (2017) Pharmacological profile and efficiency in vivo of diflapolin, the first dual inhibitor of 5-lipoxygenase-activating protein and soluble epoxide hydrolase. Sci Rep 7: 9398 [PMID:28839250]

26. Geisslinger G and Schaible HG. (1996) New insights into the site and mode of antinociceptive action of flurbiprofen enantiomers. J Clin Pharmaco/36: 513-20 [PMID:8809636]

27. Geusens P. (2009) Naproxcinod, a new cyclooxygenase-inhibiting nitric oxide donator (CINOD).Expert Opin Biol Ther 9: 649-57 [PMID:19392579]

28. Giroux A, Boulet L, Brideau C, Chau A, Claveau D, Côté B, Ethier D, Frenette R, Gagnon M and Guay let al.. (2009) Discovery of disubstituted phenanthrene imidazoles as potent, selective and orally active mPGES-1 inhibitors. Bioorg. Med. Chem. Lett. 19: 5837-41 [PMID:19748780]

29. Gorman RR, Johnson RA, Spilman CH and Aiken JW. (1983) Inhibition of platelet thromboxane A2 synthase activity by sodium 5-(3'-pyridinylmethyl)benzofuran-2-carboxylate. Prostaglandins 26: 325-42 [PMID:6316421]

30. Graham DW, Ashton WT, Barash L, Brown JE, Brown RD, Canning LF, Chen A, Springer JP and Rogers EF. (1987) Inhibition of the mammalian beta-lactamase renal dipeptidase (dehydropeptidase-I) by (Z)-2(acylamino)-3-substituted-propenoic acids. J. Med. Chem. 30: 1074-90 [PMID:3495664]

31. Gryglewski RJ, Bunting S, Moncada S, Flower RJ and Vane JR. (1976) Arterial walls are protected against deposition of platelet thrombi by a substance (prostaglandin $\mathrm{X}$ ) which they make from prostaglandin endoperoxides. Prostaglandins 12: 685-713 [PMID:824685]

32. Gryglewski RJ, Szczeklik A, Korbut R, Swies J, Musiał J, Krzanowski M and Maga P. (1995) The mechanism of anti-thrombotic, thrombolytic and fibrinolytic actions of camonagrel--a new thromboxane synthase inhibitor. Wien. Klin. Wochenschr. 107: 283-9 [PMID:7778318]

33. Han L, Hiratake J, Kamiyama A and Sakata K. (2007) Design, synthesis, and evaluation of gammaphosphono diester analogues of glutamate as highly potent inhibitors and active site probes of gammaglutamyl transpeptidase. Biochemistry 46: 1432-47 [PMID:17260973]

34. Hatae T, Hara S, Yokoyama C, Yabuki T, Inoue H, Ullrich V and Tanabe T. (1996) Site-directed mutagenesis of human prostacyclin synthase: Alteration of Cys441 of the Cys-pocket, and Glu347 and Arg350 of the EXXR motif. FEBS Lett. 389: 268-72 [PMID:8766713]

35. Hatzelmann A, Fruchtmann R, Mohrs KH, Raddatz S and Müller-Peddinghaus R. (1993) Mode of action of the new selective leukotriene synthesis inhibitor BAY X 1005 ((R)-2-[4-(quinolin-2-yl-methoxy)phenyl]-2cyclopentyl acetic acid) and structurally related compounds. Biochem. Pharmacol. 45: 101-11 [PMID:8381000]

36. Heinrich DM, Flanagan JU, Jamieson SM, Silva S, Rigoreau LJ, Trivier E, Raynham T, Turnbull AP and Denny WA. (2013) Synthesis and structure-activity relationships for 1-(4-(piperidin-1ylsulfonyl)phenyl)pyrrolidin-2-ones as novel non-carboxylate inhibitors of the aldo-keto reductase enzyme AKR1C3. Eur J Med Chem 62: 738-44 [PMID:23454516]

37. Hibi S, Okamoto Y, Tagami K, Numata H, Kobayashi N, Shinoda M, Kawahara T, Harada K, Miyamoto K and Yamatsu I. (1996) Structure-activity relationships of (E)-3-(1,4-benzoquinonyl)-2-[(3-pyridyl)-alkyl]-2propenoic acid derivatives that inhibit both 5-lipoxygenase and thromboxane A2 synthetase. J. Med. Chem. 39: 3148-57 [PMID:8759636]

38. Hieke M, Ness J, Steri R, Dittrich M, Greiner C, Werz O, Baumann K, Schubert-Zsilavecz M, Weggen S and Zettl $\mathrm{H}$. (2010) Design, synthesis, and biological evaluation of a novel class of gamma-secretase modulators with PPARgamma activity. J. Med. Chem. 53: 4691-700 [PMID:20503989]

39. Hieke M, Ness J, Steri R, Greiner C, Werz O, Schubert-Zsilavecz M, Weggen S and Zettl H. (2011) SAR studies of acidic dual y-secretase/PPARy modulators. Bioorg. Med. Chem. 19: 5372-82 [PMID:21873070]

40. Hinz B, Cheremina O and Brune K. (2008) Acetaminophen (paracetamol) is a selective cyclooxygenase-2 inhibitor in man. FASEB J. 22: 383-90 [PMID:17884974]

41. Hiraku S, Taniguchi K, Wakitani K, Omawari N, Kira H, Miyamoto T, Okegawa T, Kawasaki A and Ujiie A. (1986) Pharmacological studies on the TXA2 synthetase inhibitor (E)-3-[p-(1H-imidazol-1-ylmethyl)phenyl]2-propenoic acid (OKY-046). Jpn. J. Pharmacol. 41: 393-401 [PMID:3093741]

42. Hoshino J, Park EJ, Kondratyuk TP, Marler L, Pezzuto JM, van Breemen RB, Mo S, Li Y and Cushman M. (2010) Selective synthesis and biological evaluation of sulfate-conjugated resveratrol metabolites. J. Med. Chem. 53: 5033-43 [PMID:20527891]

43. Imanishi J, Morita Y, Yoshimi E, Kuroda K, Masunaga T, Yamagami K, Kuno M, Hamachi E, Aoki S and Takahashi F et al.. (2011) Pharmacological profile of FK881(ASP6537), a novel potent and selective 
cyclooxygenase-1 inhibitor. Biochem. Pharmacol. 82: 746-54 [PMID:21745460]

44. Inagaki M, Tsuri T, Jyoyama H, Ono T, Yamada K, Kobayashi M, Hori Y, Arimura A, Yasui K and Ohno K et al.. (2000) Novel antiarthritic agents with 1,2-isothiazolidine-1,1-dioxide (gamma-sultam) skeleton: cytokine suppressive dual inhibitors of cyclooxygenase-2 and 5-lipoxygenase. J. Med. Chem. 43: 2040-8 [PMID:10821716]

45. Irikura D, Aritake K, Nagata N, Maruyama T, Shimamoto S and Urade Y. (2009) Biochemical, functional, and pharmacological characterization of AT-56, an orally active and selective inhibitor of lipocalin-type prostaglandin D synthase. J. Biol. Chem. 284: 7623-30 [PMID:19131342]

46. Jameson 2nd JB, Kantz A, Schultz L, Kalyanaraman C, Jacobson MP, Maloney DJ, Jadhav A, Simeonov A and Holman TR. (2014) A high throughput screen identifies potent and selective inhibitors to human epithelial 15-lipoxygenase-2. PLoS ONE 9: e104094 [PMID:25111178]

47. Janusz JM, Young PA, Scherz MW, Enzweiler K, Wu LI, Gan L, Pikul S, McDow-Dunham KL, Johnson CR and Senanayake CB et al.. (1998) New cyclooxygenase-2/5-lipoxygenase inhibitors. 2. 7-tert-butyl-2,3dihydro-3,3-dimethylbenzofuran derivatives as gastrointestinal safe antiinflammatory and analgesic agents: variations of the dihydrobenzofuran ring. J. Med. Chem. 41: 1124-37 [PMID:9544212]

48. Jegerschöld C, Pawelzik SC, Purhonen P, Bhakat P, Gheorghe KR, Gyobu N, Mitsuoka K, Morgenstern R, Jakobsson PJ and Hebert H. (2008) Structural basis for induced formation of the inflammatory mediator prostaglandin E2. Proc. Natl. Acad. Sci. U.S.A. 105: 11110-5 [PMID:18682561]

49. Johnson J, Corbisier R, Stensgard B and Toft D. (1996) The involvement of p23, hsp90, and immunophilins in the assembly of progesterone receptor complexes. J. Steroid Biochem. Mol. Biol.56: 317 [PMID:8603045]

50. Kalgutkar AS, Rowlinson SW, Crews BC and Marnett LJ. (2002) Amide derivatives of meclofenamic acid as selective cyclooxygenase-2 inhibitors. Bioorg. Med. Chem. Lett. 12: 521-4 [PMID:11844663]

51. Kassab SE, Khedr MA, Ali HI and Abdalla MM. (2017) Discovery of new indomethacin-based analogs with potentially selective cyclooxygenase-2 inhibition and observed diminishing to PGE2 activities. Eur J Med Chem 141: 306-321 [PMID:29031075]

52. Kato M, Nishida S, Kitasato H, Sakata N and Kawai S. (2001) Cyclooxygenase-1 and cyclooxygenase-2 selectivity of non-steroidal anti-inflammatory drugs: investigation using human peripheral monocytes. $J$. Pharm. Pharmacol. 53: 1679-85 [PMID:11804398]

53. Kawai S, Nishida S, Kato M, Furumaya Y, Okamoto R, Koshino T and Mizushima Y. (1998) Comparison of cyclooxygenase-1 and -2 inhibitory activities of various nonsteroidal anti-inflammatory drugs using human platelets and synovial cells. Eur. J. Pharmacol. 347: 87-94 [PMID:9650852]

54. Khanapure SP, Garvey DS, Janero DR and Letts LG. (2007) Eicosanoids in inflammation: biosynthesis, pharmacology, and therapeutic frontiers. Curr Top Med Chem 7: 311-40 [PMID:17305573]

55. Kiefer JR, Pawlitz JL, Moreland KT, Stegeman RA, Hood WF, Gierse JK, Stevens AM, Goodwin DC, Rowlinson SW and Marnett LJ et al.. (2000) Structural insights into the stereochemistry of the cyclooxygenase reaction. Nature 405: 97-101 [PMID:10811226]

56. Kleinschmidt TK, Haraldsson M, Basavarajappa D, Lundeberg E, Thulasingam M, Ekoff M, Fauland A, Lehmann C, Kahnt AS and Lindbom L et al.. (2015) Tandem Benzophenone Amino Pyridines, Potent and Selective Inhibitors of Human Leukotriene C4 Synthase. J. Pharmacol. Exp. Ther. 355: 108-16 [PMID:26283693]

57. Kobayashi T, Nakatani Y, Tanioka T, Tsujimoto M, Nakajo S, Nakaya K, Murakami M and Kudo I. (2004) Regulation of cytosolic prostaglandin E synthase by phosphorylation. Biochem. J. 381: 59-69 [PMID:15040786]

58. Koeberle A, Zettl H, Greiner C, Wurglics M, Schubert-Zsilavecz M and Werz O. (2008) Pirinixic acid derivatives as novel dual inhibitors of microsomal prostaglandin E2 synthase-1 and 5-lipoxygenase. J. Med. Chem. 51: 8068-76 [PMID:19053751]

59. Kolasa T, Brooks CD, Rodriques KE, Summers JB, Dellaria JF, Hulkower KI, Bouska J, Bell RL and Carter GW. (1997) Nonsteroidal anti-inflammatory drugs as scaffolds for the design of 5-lipoxygenase inhibitors. J. Med. Chem. 40: 819-24 [PMID:9057869]

60. Kramer JS, Woltersdorf S, Duflot T, Hiesinger K, Lillich FF, Knöll F, Wittmann SK, Klingler FM, Brunst S and Chaikuad A et al.. (2019) Discovery of the First in Vivo Active Inhibitors of the Soluble Epoxide Hydrolase Phosphatase Domain. J. Med. Chem. 62: 8443-8460 [PMID:31436984]

61. Kumar R, Saha N, Purohit P, Garg SK, Seth K, Meena VS, Dubey S, Dave K, Goyal R and Sharma SSet al.. (2019) Cyclic enaminone as new chemotype for selective cyclooxygenase-2 inhibitory, antiinflammatory, and analgesic activities European Journal of Medicinal Chemistry

62. Lazer ES, Miao CK, Cywin CL, Sorcek R, Wong HC, Meng Z, Potocki I, Hoermann M, Snow RJ and Tschantz MA et al.. (1997) Effect of structural modification of enol-carboxamide-type nonsteroidal 
antiinflammatory drugs on COX-2/COX-1 selectivity. J. Med. Chem. 40: 980-9 [PMID:9083488]

63. Leclerc P, Idborg H, Spahiu L, Larsson C, Nekhotiaeva N, Wannberg J, Stenberg P, Korotkova M and Jakobsson PJ. (2013) Characterization of a human and murine mPGES-1 inhibitor and comparison to mPGES-1 genetic deletion in mouse models of inflammation. Prostaglandins Other Lipid Mediat. 107: 2634 [PMID:24045148]

64. Liu Y, Duan C, Chen H, Wang C, Liu X, Qiu M, Tang H, Zhang F, Zhou X and Yang J. (2018) Inhibition of COX-2/mPGES-1 and 5-LOX in macrophages by leonurine ameliorates monosodium urate crystal-induced inflammation. Toxicol. Appl. Pharmacol. 351: 1-11 [PMID:29763636]

65. Lolli ML, Carnovale IM, Pippione AC, Wahlgren WY, Bananni D, Marini E, Zonari D, Gallicchio M, Boscaro $\mathrm{V}$ and Goyal P et al.. (2019) Bioisosteres of Indomethacin as Inhibitors of Aldo-Keto Reductase 1C3ACS Medicinal Chemistry Letters

66. Look GC, Schullek JR, Holmes CP, Chinn JP, Gordon EM and Gallop MA. (1996) The identification of cyclooxygenase-1 inhibitors from 4-thiazolidinone combinatorial libraries. Bioorganic \& Medicinal Chemistry Letters 6: 707-712

67. Luci DK, Jameson 2nd JB, Yasgar A, Diaz G, Joshi N, Kantz A, Markham K, Perry S, Kuhn N and Yeung J et al.. (2014) Synthesis and structure-activity relationship studies of 4-((2-hydroxy-3methoxybenzyl)amino)benzenesulfonamide derivatives as potent and selective inhibitors of 12 lipoxygenase. J. Med. Chem. 57: 495-506 [PMID:24393039]

68. Luo M, Jones SM, Phare SM, Coffey MJ, Peters-Golden M and Brock TG. (2004) Protein kinase A inhibits leukotriene synthesis by phosphorylation of 5-lipoxygenase on serine 523. J. Biol. Chem. 279: 41512-20 [PMID:15280375]

69. Luz JG, Antonysamy S, Kuklish SL, Condon B, Lee MR, Allison D, Yu XP, Chandrasekhar S, Backer R and Zhang A et al.. (2015) Crystal Structures of mPGES-1 Inhibitor Complexes Form a Basis for the Rational Design of Potent Analgesic and Anti-Inflammatory Therapeutics. J. Med. Chem. 58: 4727-37 [PMID:25961169]

70. MacDonald CA, Bushnell EA, Gauld JW and Boyd RJ. (2014) The catalytic formation of leukotriene C4: a critical step in inflammatory processes. Phys Chem Chem Phys 16: 16284-9 [PMID:24974917]

71. Maddox JF and Serhan CN. (1996) Lipoxin A4 and B4 are potent stimuli for human monocyte migration and adhesion: selective inactivation by dehydrogenation and reduction. J. Exp. Med. 183: 137-46 [PMID:8551217]

72. Masferrer JL, Zweifel BS, Hardy M, Anderson GD, Dufield D, Cortes-Burgos L, Pufahl RA and Graneto M. (2010) Pharmacology of PF-4191834, a novel, selective non-redox 5-lipoxygenase inhibitor effective in inflammation and pain. J. Pharmacol. Exp. Ther. 334: 294-301 [PMID:20378715]

73. Matsuura K, Shiraishi H, Hara A, Sato K, Deyashiki Y, Ninomiya M and Sakai S. (1998) Identification of a principal mRNA species for human 3alpha-hydroxysteroid dehydrogenase isoform (AKR1C3) that exhibits high prostaglandin D2 11-ketoreductase activity. J. Biochem. 124: 940-6 [PMID:9792917]

74. Meng H, McClendon CL, Dai Z, Li K, Zhang X, He S, Shang E, Liu Y and Lai L. (2016) Discovery of Novel 15-Lipoxygenase Activators To Shift the Human Arachidonic Acid Metabolic Network toward Inflammation Resolution. J. Med. Chem. 59: 4202-9 [PMID:26290290]

75. Migliore M, Habrant D, Sasso O, Albani C, Bertozzi SM, Armirotti A, Piomelli D and Scarpelli R. (2016) Potent multitarget FAAH-COX inhibitors: Design and structure-activity relationship studies. Eur $J$ Med Chem 109: 216-37 [PMID:26774927]

76. Nandha B, Ramareddy SA and Kuntal H. (2018) Synthesis of substituted fluorobenzimidazoles as inhibitors of 5-lipoxygenase and soluble epoxide hydrolase for anti-inflammatory activity. Arch. Pharm. (Weinheim) 351: e1800030 [PMID:29732612]

77. Ochi T, Motoyama Y and Goto T. (2000) The analgesic effect profile of FR122047, a selective cyclooxygenase-1 inhibitor, in chemical nociceptive models. Eur. J. Pharmacol. 391: 49-54 [PMID:10720634]

78. Oh SF, Pillai PS, Recchiuti A, Yang R and Serhan CN. (2011) Pro-resolving actions and stereoselective biosynthesis of $18 \mathrm{~S}$ E-series resolvins in human leukocytes and murine inflammation. J. Clin. Invest.121: 569-81 [PMID:21206090]

79. Orning L, Krivi G and Fitzpatrick FA. (1991) Leukotriene A4 hydrolase. Inhibition by bestatin and intrinsic aminopeptidase activity establish its functional resemblance to metallohydrolase enzymes. J. Biol. Chem. 266: 1375-8 [PMID:1846352]

80. Ottanà R, Carotti S, Maccari R, Landini I, Chiricosta G, Caciagli B, Vigorita MG and Mini E. (2005) In vitro antiproliferative activity against human colon cancer cell lines of representative 4-thiazolidinones. Part I. Bioorg. Med. Chem. Lett. 15: 3930-3 [PMID:15993594]

81. Ozen G, Gomez I, Daci A, Deschildre C, Boubaya L, Teskin O, Uydeş-Doğan BS, Jakobsson PJ, Longrois 
D and Topal G et al.. (2017) Inhibition of microsomal PGE synthase-1 reduces human vascular tone by increasing PGI2 : a safer alternative to COX-2 inhibition. Br. J. Pharmacol. 174: 4087-4098 [PMID:28675448]

82. P JJ, Manju SL, Ethiraj KR and Elias G. (2018) Safer anti-inflammatory therapy through dual COX-2/5LOX inhibitors: A structure-based approach. Eur J Pharm Sci121: 356-381 [PMID:29883727]

83. Penning TD, Chandrakumar NS, Chen BB, Chen HY, Desai BN, Djuric SW, Docter SH, Gasiecki AF, Haack RA and Miyashiro JM et al.. (2000) Structure-activity relationship studies on 1-[2-(4Phenylphenoxy)ethyl]pyrrolidine (SC-22716), a potent inhibitor of leukotriene A(4) (LTA(4)) hydrolase. J. Med. Chem. 43: 721-35 [PMID:10691697]

84. Penning TD, Talley JJ, Bertenshaw SR, Carter JS, Collins PW, Docter S, Graneto MJ, Lee LF, Malecha JW and Miyashiro JM et al.. (1997) Synthesis and biological evaluation of the 1,5-diarylpyrazole class of cyclooxygenase-2 inhibitors: identification of 4-[5-(4-methylphenyl)-3-(trifluoromethyl)-1 H-pyrazol-1yl]benze nesulfonamide (SC-58635, celecoxib). J. Med. Chem. 40: 1347-65 [PMID:9135032]

85. Penrose JF, Spector J, Baldasaro M, Xu K, Boyce J, Arm JP, Austen KF and Lam BK. (1996) Molecular cloning of the gene for human leukotriene $\mathrm{C} 4$ synthase. Organization, nucleotide sequence, and chromosomal localization to 5q35. J. Biol. Chem. 271: 11356-61 [PMID:8626689]

86. Prasher P, Pooja and Singh P. (2014) Lead modification: amino acid appended indoles as highly effective 5-LOX inhibitors. Bioorg. Med. Chem. 22: 1642-8 [PMID:24508141]

87. Qiu W, Zhou M, Mazumdar M, Azzi A, Ghanmi D, Luu-The V, Labrie F and Lin SX. (2007) Structure-based inhibitor design for an enzyme that binds different steroids: a potent inhibitor for human type 5 17betahydroxysteroid dehydrogenase. J. Biol. Chem. 282: 8368-79 [PMID:17166832]

88. Rai G, Joshi N, Perry S, Yasgar A, Schultz L, Jung JE, Liu Y, Terasaki Y, Diaz G and Kenyon Vet al.. (2010) Discovery of ML351, a Potent and Selective Inhibitor of Human 15-Lipoxygenase-1 Probe Reports from the NIH Molecular Libraries Program [PMID:24672829]

89. Rai G, Kenyon V, Jadhav A, Schultz L, Armstrong M, Jameson JB, Hoobler E, Leister W, Simeonov A and Holman TR et al.. (2010) Discovery of potent and selective inhibitors of human reticulocyte 15lipoxygenase-1. J. Med. Chem. 53: 7392-404 [PMID:20866075]

90. Randall MJ, Parry MJ, Hawkeswood E, Cross PE and Dickinson RP. (1981) UK-37, 248, a novel, selective thromboxane synthetase inhibitor with platelet anti-aggregatory and anti-thrombotic activity. Thromb. Res. 23: 145-62 [PMID:6795753]

91. Rao NL, Riley JP, Banie H, Xue X, Sun B, Crawford S, Lundeen KA, Yu F, Karlsson L and Fourie ANet al.. (2010) Leukotriene $A(4)$ hydrolase inhibition attenuates allergic airway inflammation and hyperresponsiveness. Am. J. Respir. Crit. Care Med.181: 899-907 [PMID:20110560]

92. Riendeau D, Aspiotis R, Ethier D, Gareau Y, Grimm EL, Guay J, Guiral S, Juteau H, Mancini JA and Méthot $\mathrm{N}$ et al.. (2005) Inhibitors of the inducible microsomal prostaglandin E2 synthase (mPGES-1) derived from MK-886. Bioorg. Med. Chem. Lett. 15: 3352-5 [PMID:15953724]

93. Riendeau D, Percival MD, Brideau C, Charleson S, Dubé D, Ethier D, Falgueyret JP, Friesen RW, Gordon $\mathrm{R}$ and Greig $\mathrm{G}$ et al.. (2001) Etoricoxib (MK-0663): preclinical profile and comparison with other agents that selectively inhibit cyclooxygenase-2. J. Pharmacol. Exp. Ther. 296: 558-66 [PMID:11160644]

94. Ronn R, Lindh CJ, Ringberg E, Andersson EHB, Nilsson P, Schall WR, Munk af RM, Nikitidis A, Nikitidis $G$ and Johannesson PJ et al.. (2016) Cyclopropane carboxylic acid derivatives and pharmaceutical uses thereof Patent number: WO2016177845.

95. Sadik CD, Sies H and Schewe T. (2003) Inhibition of 15-lipoxygenases by flavonoids: structure-activity relations and mode of action. Biochem. Pharmacol. 65: 773-81 [PMID:12628491]

96. Sandanayaka V, Mamat B, Mishra RK, Winger J, Krohn M, Zhou LM, Keyvan M, Enache L, Sullins D and Onua E et al.. (2010) Discovery of 4-[(2S)-2-\{[4-(4-chlorophenoxy)phenoxy]methyl\}-1-pyrrolidinyl]butanoic acid (DG-051) as a novel leukotriene A4 hydrolase inhibitor of leukotriene B4 biosynthesis. J. Med. Chem. 53: 573-85 [PMID:19950900]

97. Shiro T, Kakiguchi K, Takahashi H, Nagata H and Tobe M. (2013) 7-Phenyl-imidazoquinolin-4(5H)-one derivatives as selective and orally available mPGES-1 inhibitors. Bioorg. Med. Chem. 21: 2868-78 [PMID:23623673]

98. Singh P, Kaur S, Kaur J, Singh G and Bhatti R. (2016) Rational Design of Small Peptides for Optimal Inhibition of Cyclooxygenase-2: Development of a Highly Effective Anti-Inflammatory Agent. J. Med. Chem. 59: 3920-34 [PMID:27019010]

99. Singh P, Prasher P, Dhillon P and Bhatti R. (2015) Indole based peptidomimetics as anti-inflammatory and anti-hyperalgesic agents: Dual inhibition of 5-LOX and COX-2 enzymes. Eur J Med Chem 97: 104-23 [PMID:25956953]

100. Sinha S, Doble M and Manju SL. (2018) Design, synthesis and identification of novel substituted 2-amino 
thiazole analogues as potential anti-inflammatory agents targeting 5-lipoxygenase. Eur J Med Chem 158: 34-50 [PMID:30199704]

101. Skarydová L, Zivná L, Xiong G, Maser E and Wsól V. (2009) AKR1C3 as a potential target for the inhibitory effect of dietary flavonoids. Chem. Biol. Interact. 178: 138-44 [PMID:19007764]

102. Smith CJ, Zhang Y, Koboldt CM, Muhammad J, Zweifel BS, Shaffer A, Talley JJ, Masferrer JL, Seibert K and Isakson PC. (1998) Pharmacological analysis of cyclooxygenase-1 in inflammation. Proc. Natl. Acad. Sci. U.S.A. 95: 13313-8 [PMID:9789085]

103. Stsiapanava A, Samuelsson B and Haeggström JZ. (2017) Capturing LTA hydrolase in action: Insights to the chemistry and dynamics of chemotactic LTB 4 synthesis. Proc. Natl. Acad. Sci. U.S.A. 114: 9689-9694 [PMID:28827365]

104. Takahashi T and Miyazawa M. (2012) N-Caffeoyl serotonin as selective COX-2 inhibitor.Bioorg. Med. Chem. Lett. 22: 2494-6 [PMID:22386242]

105. Talley JJ, Brown DL, Carter JS, Graneto MJ, Koboldt CM, Masferrer JL, Perkins WE, Rogers RS, Shaffer AF and Zhang YY et al.. (2000) 4-[5-Methyl-3-phenylisoxazol-4-yl]- benzenesulfonamide, valdecoxib: a potent and selective inhibitor of COX-2. J. Med. Chem. 43: 775-7 [PMID:10715145]

106. Tholander F, Muroya A, Roques BP, Fournié-Zaluski MC, Thunnissen MM and Haeggström JZ. (2008) Structure-based dissection of the active site chemistry of leukotriene A4 hydrolase: implications for M1 aminopeptidases and inhibitor design. Chem. Biol. 15: 920-9 [PMID:18804029]

107. Verma K, Gupta N, Zang T, Wangtrakluldee P, Srivastava SK, Penning TM and Trippier PC. (2018) AKR1C3 Inhibitor KV-37 Exhibits Antineoplastic Effects and Potentiates Enzalutamide in Combination Therapy in Prostate Adenocarcinoma Cells. Mol. Cancer Ther. 17: 1833-1845 [PMID:29891491]

108. Viegas A, Manso J, Corvo MC, Marques MM and Cabrita EJ. (2011) Binding of ibuprofen, ketorolac, and diclofenac to COX-1 and COX-2 studied by saturation transfer difference NMR. J. Med. Chem. 54: 8555-62 [PMID:22091869]

109. Wannberg J, Alterman M, Malm J, Stenberg P, Westman J and Wallberg H. (2011) Microsomal prostaglandin e synthase-1 (mpges1) inhibitors Patent number: WO2011023812.

110. Warner TD, Giuliano F, Vojnovic I, Bukasa A, Mitchell JA and Vane JR. (1999) Nonsteroid drug selectivities for cyclo-oxygenase-1 rather than cyclo-oxygenase-2 are associated with human gastrointestinal toxicity: a full in vitro analysis. Proc. Natl. Acad. Sci. U.S.A. 96: 7563-8 [PMID:10377455]

111. Watanabe K, Ohkubo H, Niwa H, Tanikawa N, Koda N, Ito S and Ohmiya Y. (2003) Essential 110Cys in active site of membrane-associated prostaglandin E synthase-2. Biochem. Biophys. Res. Commun. 306: 577-81 [PMID:12804604]

112. Weinstein DS, Liu W, Ngu K, Langevine C, Combs DW, Zhuang S, Chen C, Madsen CS, Harper TW and Robl JA. (2007) Discovery of selective imidazole-based inhibitors of mammalian 15-lipoxygenase: highly potent against human enzyme within a cellular environment. Bioorg. Med. Chem. Lett. 17: 5115-20 [PMID:17656086]

113. Wilkerson WW, Copeland RA, Covington M and Trzaskos JM. (1995) Antiinflammatory 4,5-diarylpyrroles. 2. Activity as a function of cyclooxygenase-2 inhibition. J. Med. Chem. 38: 3895-901 [PMID:7562922]

114. Wu Y, Karna S, Choi $\mathrm{CH}$, Tong M, Tai HH, Na DH, Jang CH and Cho H. (2011) Synthesis and biological evaluation of novel thiazolidinedione analogues as 15 -hydroxyprostaglandin dehydrogenase inhibitors. $J$. Med. Chem. 54: 5260-4 [PMID:21650226]

115. Yu Z, Schneider C, Boeglin WE, Marnett LJ and Brash AR. (2003) The lipoxygenase gene ALOXE3 implicated in skin differentiation encodes a hydroperoxide isomerase. Proc. Natl. Acad. Sci. U.S.A.100: 9162-7 [PMID:12881489]

116. Zhou H, Liu W, Su Y, Wei Z, Liu J, Kolluri SK, Wu H, Cao Y, Chen J and Wu Yet al.. (2010) NSAID sulindac and its analog bind RXRalpha and inhibit RXRalpha-dependent AKT signaling. Cancer Cell 17: 560-73 [PMID:20541701]

117. Zimmermann TJ, Niesen FH, Pilka ES, Knapp S, Oppermann U and Maier ME. (2009) Discovery of a potent and selective inhibitor for human carbonyl reductase 1 from propionate scanning applied to the macrolide zearalenone. Bioorg. Med. Chem. 17: 530-6 [PMID:19097799]

118. Zou J, Jin D, Chen W, Wang J, Liu Q, Zhu X and Zhao W. (2005) Selective cyclooxygenase-2 inhibitors from Calophyllum membranaceum. J. Nat. Prod.68: 1514-8 [PMID:16252917] 